\title{
CLAIMING AND DISCLAIMING THE BODY IN THE EARLY DIARIES OF VIRGINIA WOOLF, ANAIIS NIN AND AINO KALLAS
}

LEENA KURVET-KÄOSAAR

University of Tartu (Estonia)

Autobiographical practices, as realized and conceptualized in the $20^{\text {th }}$ century have, to a great extent, ignored the issues pertaining to the body. Shirley Neumann sees as one of the main reasons for this "the Platonic tradition that opposes the spiritual to the corporeal, and then identifies 'self' with the spiritual»". In later considerations of autobiography that have been influenced by the postmodernist paradigm, the rationalist 'self' is replaced by the notion of the subject that views linguistic constructions of the self, or, in other words, textual markers of the subject as part of historic, social and cultural factors. According to Sidonie Smith, "subjectivity is not an out-of-body experience»"; rather it can be viewed as "the elaborate residue of the border politics of the body since bodies locate us topographically, temporally, socio-culturally as well as linguistically in a series of transcodings along multiple axes of meanings ${ }^{3}$. By declaring that "the body has been made so problematic for women that it has often seemed easier to shrug it off and travel as a disembodied spirit $»^{4}$, Adrienne Rich voices an experience familiar to women belonging to various cultures, classes, ages and racial/ethnic backgrounds.

The Cartesian mind/body split placing women on the latter side of the divide has historically resulted in a textual neutralization or writing off the body in women's autobiographical texts. Several feminist autobiography scholars have argued that despite its problematic nature, the body is not

1. Neuman, Shirley: «'An appearance walking in a forest the sexes burn': Autobiography and the Construction of the Feminine Body", in Kathleen Ashley, Leigh Gilmore and Gerald Peters (eds.): Autobiography \& Postmodernism, Amherst, University of Massachusetts Press, 1994, p. 293.

2. SмrтH, Sidonie: «Identity's Body», in Kathleen Ashley, Leigh Gilmore and Gerald Peters (eds.), Autobiography \& Postmodernism, Amherst, University of Massachusetts Press, 1994, p. 266.

3. SMITH, Sidonie: Op. cit., p. 267.

4. Rich, Adrienne: Of Women Born: Motherhood as Experience and Institution, New York, W.W. Norton, 1976, p. 40. 
entirely absent from women's autobiographical writings. As Smith further argues, "the women autobiographer always remained self-consciously in her body even as she erased the body from her text»". The word 'erasure' here does not denote a mere absence but rather a presence that has been removed, or even more importantly, a presence that is continuously in the process of coming into being and being removed. Even with no visible readable presence, "(in autobiography) the body of the text, the body of the narrator, the body of the narrated I, the cultural body and the body politic must all merge in skins and skeins of meaning ${ }^{6}$.

Keeping a diary, especially for women, has been a practice of considerable continuity in the Western Culture. In an insightful attempt to conceptualize the diary, Felicity Nussbaum claims; «it is possible that women began the idea of private and later public, articulation of quotidian experience ${ }^{7}$. The diary, looked upon as a textual practice both formally and thematically corresponding to women's pattern of life and way of thinking, has frequently been considered to be the 'feminine mode of writing' by feminist critics of autobiography ${ }^{8}$. While an exposure of the ways in which diaristic writings have been feminized and rejected in the classical theoretical and critical works on autobiography, it can certainly be considered a noteworthy contribution to autobiography criticism, the construction of the textual space of the diary as a safe secluded haven for the female pen runs, at some point, the risk of furthering the feminization and marginalization of the diary rather than expanding the autobiographical canon. An understanding of the diary format as a mode of writing that has been accessible and gratifying for women across centuries ${ }^{9}$, however, makes it possible to view women's diaries as important sources providing access to the representation of the development of female subjectivity.

In many cases, women's diaries start with adolescence or girlhood. A renowned French scholar of autobiography, Philippe Lejeune, who has studied the diaries of French girls from the $17^{\text {th }}$ century onwards, sees as the most difficult task in reading young girls diaries «in learning how to decipher the code or thematic framework within which the diary articulates itself $\rangle^{10}$. Lejeune mentions as one of the characteristic features of girlhood diaries the high degree of self-censorship, ${ }^{11}$ everything pertaining to the body falling into the category

5. Smith, Sidonie: Op. cit., p. 272.

6. Ibid., p. 267.

7. Nussbaum, Felicity: "Toward Conceptualizing the Diary», in James Olney (ed.): Studies in Autobiography, Oxford, Oxford University Press, 1988, p. 134.

8. See, for example, Moffat, Mary Jane, and Painter, Charlotte: Revelations: Diaries of Women, New York, Vintage, 1974, p. 5. HogAn, Rebecca: «Diarists on Diaries», a/b: Auto/Biography Studies, 2.2 (1986), p. 100.

9. Blodgett, Harriet: Centuries of Female Days. Englishwomen's Private Diaries, New Brunswick, Rutgers University Press, 1988, p. 5.

10. Lejeune, Philippe: "The 'Journal de Jeune Fille' in Nineteenth-Century France», in Bunkers, Suzanne L. and Cynthia A. Huff, Inscribing the Daily. Critical Essays on Women's Diaries, Amherst, University of Massachusetts Press, 1996, p. 111.

11. Lejeune, Philippe: Op. cit., p. 111. 
of topics to be left out of the diary. "A girl could keep a diary", claims Lejeune, "without any interruption, between the ages of eight and seventeen, without mentioning at all any transformations brought about by puberty ${ }^{12}$. The diaries of girlhood, adolescence and young womanhood offer extremely valuable insights into the textual negotiational practices through which women have attempted to locate themselves in their surroundings and contexts as well as their bodies. Nussbaum identifies the need for keeping a diary with the point when «the subject begins to believe that it cannot be intelligible to itself without written representation and articulation ${ }^{13}$. Considering both the intellectual and ideological ways of male-dominated Western culture that submits women to multiple objectifying practices from quite an early age, it is not difficult to see why a written articulation and representation of experience has been of such crucial value for young women across various cultural contexts and time frames.

According to Bunkers and Huff, "women's daily experience» that has been articulated in the diary, "has been denigrated by mainstream Western epistemology in favor of universality is commonly related to the bodily and separated from the universality [of the mind in favor of the latter]» ${ }^{14}$. The binary opposition of mind and body, although commonly associated with Descartes, can be traced back to Plato, who views the body as a "tomb, or as a grave or a prison for the soul» ${ }^{15}$. Claiming that women live more through their bodies than men, Plato views the body as an enormous obstacle in seeing beauty, achieving knowledge and the highest forms of love ${ }^{16}$. Women's lives are seen as more related to the body than those of men and the diary has been viewed as a textual practice that, more than any other autobiographical discourse, as if bears trace of the operation of binary thought.

On the one hand, the diary is positioned in the canon of autobiography as a textual practice pertaining more to the body (characterized by qualities such as immanence, the daily, and being of local relevance) than to the mind (characterized by qualities such as universality and transcendence). On the other hand, as a rather loosely conceptualized and flexible genre the diary offers more varied and richer possibilities for writing the body. Diaries can be also viewed as having a positive relation to the body, as offering a home to the textual \& textured body of the author's subjectivity. When keeping a diary, she calls into being a text that continually expands in time and space, the author

12. Ibid., p. 111.

13. Nussbaum, Felicity: Op. cit., p. 132.

14. Bunkers, Suzanne and Huff, Cynthia: «Issues in Studying Women's Diaries: A Theoretical and Critical Introduction", in Suzanne Bunkers and Cynthia Huff (eds.): Inscribing the Daily; Critical Essays on Women's Diaries, Amherst, University of Massachusetts Press, 1996, p. 5.

15. Spelman, Elizabeth V.: "Woman as Body: Ancient and Contemporary Views», Feminist Studies, 8-1 (spring 1982), p. 136.

16. Spelman, Elizabeth V.: Op. cit., pp. 36, 37. 
gradually claims a textual body, she possesses a text and is simultaneously contained by it.

As the diary is "experienced as writing without an end" ${ }^{17}$, it lacks a pressure for closure, the need to declare itself finished, it acquires over time a more intimate and more immediate, or one may say more bodily, relation with its author. This is a feature that is characteristic of all diary texts that cover long periods of their authors' lives. It is clear for the reader that the diary is for its author a familiar and reliable writing situation or context, to which she is related via the dynamic patterns of previous entries. This, however, does not imply an obligation of the author to continue reproducing the style, length, mode and referential framework of previous entries. On the contrary, the familiarity of the context can be traced in the freedom of the author to vary and modify format and structure of the diary according to his/her needs.

Virginia Woolf, Anaïs Nin and Aino Kallas kept a diary more or less regularly for long periods of their lives. Virginia Woolf is the only one of the three women who did not publish her diary during her lifetime. Her diary, nevertheless, demonstrates an awareness of the possibility of letting go of the text for publication eventually. Both Aino Kallas and Anaïs Nin edited and published their diaries toward the end of their lives. For long periods of their lives though, the diary, kept more or less on a daily basis, remained a private body of text and did not enter "the realm of shared experience as works of literature do» ${ }^{18}$. The diaries of Virginia Woolf, Anaïs Nin and Aino Kallas display from the very first entries a relatively strong awareness of the characteristic features of textual production, including "an urge to give shape and meaning to life with words and to endow this meaning-making with a permanence that transcends time $»^{19}$. All three diaries carefully document the publication of their authors' first pieces of writing. Although achieving literary fame is at that point several decades away from all three women, the diaries engage in what can be called a preparation for the profession of letters and reveal an increasing awareness of the process of textual production. Virginia Stephen's and Aino Krohn's diaries also play an especially important role as writers'sketchbooks. In Aino Krohn's diary this can be traced in the structure as well as in several comparisons of the diary (and life) with a novel ${ }^{20}$. In Virginia Stephen's diary this is noticeable in various entries that resemble the essay format, differing considerably from the range of topics and daily structure of her later diary. The awareness of that

17. Lejeune, Philippe: «How Do Diaries End?», Biography: An Interdisciplinary Quarterly, 24-1 (winter 2001), p. 100.

18. Dalsimer, Katherine: Female Adolescence. Psychoanalytic Reflections on Literature, New Haven, Yale University Press, 1986, p. 2.

19. Culley, Margo: «Introduction», in Margo Culley (ed.): A Day at a Time: Diary Literature of American Women, from 1764 to 1985, New York, The Feminist Press at The City University of New York, 1985 , p. 11

20. See also Makronen, Anna: «My Own Novel. Yes, really!», Scandinavian Studies, 71-4 (winter 1999), pp. 419-452. 
vocation and the backgrounds of all three young women certainly caution the reading of the diaries as representative of average adolescent girls or young women of their respective temporal and cultural contexts.

My article focuses on the textual presence and absence of the body as a basis of formational processes of identity in the early diaries of Virginia Woolf, Anaiis Nin, and Aino Kallas. The early diaries of three outstanding women authors of the $20^{\text {th }}$ century, covering the period of adolescence to womanhood, offer extremely interesting insights into the bodily processes of gendered identity-construction, the textual presence and absence of the body as the basis of autobiographical identification, the relationship between the public and private bodies and the traces of body politics in the diaries. I will be looking at the following volumes: A Passionate Apprentice: The Early Diary of Virginia Woolf (1897-1909)21, Virginia Stephen aged 15 to 27, The Early Diary of Anais Nin, Volume II (1920-1923)22, Nin aged 17 to 21 and Pärjapunuja: päevaraamat aastaist 1897-190623, Aino Krohn/Kallas aged 19 to 28.

Virginia Stephen's diaristic records of adolescence and young womanhood, varying in both content and form were edited for publication by Mitchell Leaska in 1990 bearing the title A Passionate Apprentice. The childhood, adolescence and young womanhood of Anais Nin is quite thoroughly documented in a posthumously published series of four volumes titled the Early Diary of Anaiis Nin. ${ }^{24}$ The earliest diaries of Aino Kallas have not been preserved as the author herself later destroyed the volumes covering her school years ${ }^{25}$. It is for this reason that the diary of Aino Kallas starts on the threshold of womanhood, when the author is 19 years old.

The early diaries of Virginia Woolf, Anaïs Nin, and Aino Kallas cover a relatively similar period in the authors' lives. At the same time, the three women belong to different cultural spaces as well as slightly different timeframes. They share a rather similar background, all coming from outstanding and financially well-off families in their respective cultural contexts. Aino Krohn comes from a distinguished Finnish family of intellectuals, men (and women) of letters and public figures of Finnish national awakening. Virginia Stephen's father Leslie Stepen was a prominent Victorian intellectual and the first editor of the Dictionary of National Biography, Anais Nin's family background from her mother's side was a well-off and artistic Cuban-Danish-French family residing in Cuba. All three women spent their childhood in both intellectually

21. Woolf, Virginia: A Passionate Apprentice: The Early Journals, 1897-1909, New York, London, Harcourt Brace Jovanovich, 1990.

22. Nin, Anaïs: The Early Diary of Anaïs Nin, Volume II, 1920-1923, New York, London, Harcourt Brace Jovanovich, 1982.

23. Kallas, Aino: Pärjapunuja: päevaraamat aastaist 1897-1906, Tallinn, Eesti Raamat, 1994.

24. Linotte: The Early Diary of Anais Nin 1914-1920 (New York, Harvest Books, 1980), The Early Diary of Anaïs Nin, Volume II, 1920-1923 (New York, London, Harcourt Brace Jovanovich, 1982), Journal of A Wife: the Early Diary of Anais Nin, 1923-1927 (London, Peter Owen Publishers, 1984) and The Early Diary of Anais Nin, 1927-1930 (New York, Harcourt Brace Jovanovich, 1985).

25. LaITInen, Kai: Aino Kallas, Tallinn, Sinisukk, 1997, p. 561. 
and financially affluent surroundings that for all of them were also darkened by traumatic personal losses. Aino Krohn's beloved father drowned on a boat trip in 1888 when Aino was 10 years old. Virginia Woolf lost her mother in 1895 at the age of 13, her half-sister Stella two years later and her father in 1904. Anaïs Nin's life was changed forever when her father abandoned the family and Anaïs had to suffer a painful loss of her familiar European cultural context and follow her mother and two brothers to the USA. When reading the diaries, it is very important to observe the relationship of the authors with their family members as well as with the surrounding world. Anaïs Nin's early diary reveals a rather withdrawn position of its author in her family, that, in turn, is marginal in its new socio-cultural settings in the USA. The reserved position of Virginia Stephen can be partially attributed to the loss of her parents and half-sister and her first outbreaks of mental instability as well as possible sexual harassment by two half-brothers. ${ }^{26}$ The premarital years of Aino Krohn have been depicted in the diary from the position of full participation (and enjoyment) of the events and processes open to a young woman of her upbringing and background in her society. The author's status, however, changes radically right after marriage and she moves to St. Petersburg where the world of Aino Kallas, cut off from her Finnish roots, is suddenly reduced to home and the care of her children. Although not all differences in the depiction of the body and embodied subjectivity in the three diaries can be attributable to differences in cultural context and time frame, these are, nonetheless, factors that need to be accounted for.

Virginia Stephen's A Passionate Apprentice opens when Virginia was recovering from a nervous breakdown following her mother's death in May 1895. ${ }^{27}$ Between this January and the autumn of 1904 she would also witness the deaths of her half-sister Stella and of her father and survive "a summer of madness and suicidal depression ${ }^{28}$. Autumn 1904, when she started assisting a family friend Frederic Maitland with her father's biography, also marks the starting point of Virginia's career as a writer. In January 1905 she accepted a weekly teaching post at Morley College, an evening institute for working men

26. Woolf writes about it only at the end of her life, in a posthumously published autobiographical sketch Moments of Being (New York, Harcourt Brace Jovanovich, 1985). This aspect of Virgina Woolf's life is also touched upon in all later biographies of her. One of the earliest and also most thorough considerations of this theme Virginia Woolf. The Impact of Childhood Sexual Abuse on Her Life and Work (London, The Women's Press Ltd., 1989) was written by Louise DeSalvo who deconstructs the myths of Virginia's childhood home as a safe environment supporting harmonious development of the children, exposing several formerly unknown details concerning almost all family members.

27. LeASKA, Mitchell A: "Introduction», in Virginia Woolf: A Passionate Apprentice: The Early Journals, 1897-1909, New York, London, Harcourt Brace Jovanovich, 1990, p. xv; DaLsimer, Katherine: Virginia Woolf. Becoming a Writer, New Haven, Yale University Press, 2001, p. 39.

28. LeasKa, Mitchell A.: Op. cit., p. xv. 
and women, in December 1904 three of her reviews were published in The Guardian, and in February 1905 she received an invitation to review books for the Times Literary Supplement.

According to Katherine Dalsimer, "what her adolescent diary reveals is that as early as age fifteen, writing was for Virginia Woolf as painting was for Lily Briscoe, "the one dependable thing in a world of strife, ruin and chaos ${ }^{29}$. The first entries from the years 1897 and 1899 are a rather laconic record of daily events. The next volumes, following a less strict and structured writing mode, demonstrate how the textual space of the diary becomes more familiar for the author and how, in order to find a diaristic style of her own, she is starting to feel freer to engage in textual experiments. In addition to documenting daily events, the diary now contains several entries that strive to produce a textual record of a mode or an atmosphere as well as other contemplations of more general nature.

As A Passionate Apprentice is rather incoherent in both the style of writing and the range of topics discussed, it would be quite difficult to provide a conclusive overview of the relation between body and subjectivity in it. Characteristically to Woolf's later diary volumes as well, the body is perceivable more through absence than through presence. Differing from the diaries of both Anaïs Nin and Aino Kallas, Virginia Stephen's diary contains no entries that would provide the reader with information about the looks of the author neither her attitude toward her appearance. The diary also contains few, if any, descriptions of social events that a girl of her age and background would normally participate in. One diary entry, however, contains a description of a dance that Virginia attended together with her sister. If Aino Krohn's diary contains several engaging descriptions of various dances and the diary of Anais Nin diary occasionally touches upon the at least partially enjoyable effect of such events, Virginia Stephen's attitude is clearly refractory. More than anything else, Virgina resists forced close physical contact with other people at the dance. Finding herself «shoved well into a thick knot of human beings $»^{30}$, Virginia's only wish is to escape from the crowd «trying to seize arms \& waists $\&$ hurl each other thus united into the waltzing center of the room $»^{31}$.

The one bodily theme that keeps popping up in various contexts in $A$ Passionate Apprentice is that of illness and death. The diary provides descriptions of minor colds and toothaches as well as serious diseases resulting in death. Illness is certainly one of the topics that interested Woolf all through her literary career. In her essay "On Illness", published in 1926, Woolf emphasizes the bodily basis of all life experience as such:

29. Dalsimer, Katherine: Op. cit., p. 56.

30. Woolf, Virgina: A Passionate Apprentice..., op. cit., p. 170.

31. Woolf, Virginia: Op. cit., p. 170. 
"All day, all night the body intervenes /.../ the creature within can only gaze through the pane-smudged or rosy; it cannot separate off from the body like the sheath of a knife or the pod of a pea for a single instant. $)^{32}$

Woolf also emphasizes the need to coin a new language, "primitive, subtle, sensual, obscene» ${ }^{33}$ as well as a "new hierarchy of the passions» where "love must be deposed in favor of a temperature of 104; jealousy give place to the pangs of sciatica ${ }^{34}$ that would provide the experience of being ill a place among the great themes of literature.

Of all bodily ailments, A Passionate Apprentice most noticeably focuses on various dental problems. The reason for this is probably not the relevance of dental problems in young Virginia Stephen's life as such but in the fact that this was an issue that was least related to various taboos concerning the body. It is also important that dental problems, though bothersome, hardly constituted a problem involving any serious health risks. The following example conveys a typical mood of the descriptions of several visits to the dentist included in the diary:

"At 3:30 I was in Tisdall's chair \& sat there an hour of an acute discomfort \& some pain having a tooth stopped \& that infernal crown jammed into my jaw which was finally done - but it aches (illegible) at this minute. $\aleph^{35}$

Descriptions of Virginia's visits to the dentist all share certain similar features. In all cases, the perspective conveyed is very much that of a passive object of the medial practice. In the above quoted section, the body emerges to signal acute discomfort coming not from itself but from the process of "having that infernal crown jammed» into Virginia's jaw. Woolf's description of the procedure implies being subjected to violent and aggressive medical act that calls into question the efficiency of the treatment, the act of fixing the body itself.

Virginia started her diary after a period of mental instability following her mother's death. As between January 1897 when the diary opens and 1904 she would also witness her half-sister Stella dying of peritonitis and her father dying of abdominal cancer, the reader half expects health related issues enjoying a solid presence in her diary but has to put up with a rather scanty and laconic textual record. It is also interesting to note that although Virginia's family members' bodily well-being was, through their illnesses, threatened from the inside, the diary displays an extensive, at times almost hyperbolic awareness of the common threats to the body by the outside worlds. During Stella's illness, for example, the diary contains various descriptions of carriage and omnibus accidents made in a rather alarmed tone.

32. Woolf, Virginia: «On Being Ill,» The Essays of Virginia Woolf, Volume IV, 1925-1928, London, The Hogarth Press, 1994, p. 318.

33. Woolf, Virginia: «On Being Ill», op. cit., p. 319.

34. Ibid. p. 319.

35. Woolf, Virgina: A Passionate Apprentice, op. cit., pp. 226-227. 
Claiming and Disclaiming the Body in the Early Diaries of Virginia Woolf....

A Passionate Apprentice also contains entries immediately preceding and following Stella's death. Virginia had not been feeling well the preceding days and upon her visit to Stella (who lived across the street) her mental condition was considered vulnerable enough as not to risk transporting her to her own home that was in fact, only a few houses away. Virginia spends the last days of Stella's life in the room next-door, so-to-say, sharing Stella's condition of being ill. Virginia's diary entries from the period when Stella returned from her honeymoon in poor health demonstrate a continuous concern for Stella's health. This is evident from the fact that each entry contains a brief description of Stella's condition as well as comments on the opinions of the doctors. Several entries demonstrate how Virginia sees a discord between the optimistic prognoses of the doctors and how well Stella seems to be. The entries concerning the final stages of Stella's illness that seem to make an attempt to record the gradual fading away of Stella's physical presence and its final dissolution, are made retrospectively as Virginia did not have her diary with her during the days she spent at Stella's house.

The entries show intensive dedication to remembering and documenting every moment spent with Stella and every word exchanged between the two women. Other family members are referred to by their proper names, Stella by the personal pronoun 'she'. Virginia concentrates on Stella gradual physical detachment from Virginia. During the first day of her visit, Stella stays up with Virginia all through the night "stroking [her] till the fidgets went.» ${ }^{36}$ Virginia sees Stella once more in passing and then the only contact between them is via voice: laying in bed in different rooms they call out for each other's health. When Virginia is transported to her house a day later, Stella cannot be present in person to see her off but she extends her material and maternal presence via lending Virginia her fur cape, into which Virginia is wrapped.

The entry recording Stella's death however, is not only devoid of emotion but also displays an interesting dispersal of voice, a dissolving of the speaking ' $\mathrm{I}$ ':

"At 3 this morning, Georgie \& Nessa came to me, \& told me that Stella was dead

- That is all we have thought of since, $\&$ it is impossible to write of ${ }^{37}$

First, Virginia is being told the news, then the position of her receiving information from George \& Nessa shifts to an unelaborated 'we' and finally to a declaration of writer's block obviously referring to Virginia's writing but marked by an impersonal pronoun. The next page, though dated, remains blank in the diary. The blankness of the page, in my opinion, can be viewed as a non-verbal presence of Stella's death, the materiality of the blank page conveying the reality of her death and the material absence or a void created by it. By the blank page death acquires a physical presence, a space is allotted in the diary for that, reminding of the custom of commemorating those who have passed away by a moment of silence.

36. Ibid., p. 114.

37. Ibid., p. 115. 
When Nin left Barcelona for New York in the autumn of 1914, she began writing in French what she later called her childhood diary ${ }^{38}$. For Nin, the diary was first and foremost a means to communicate with her absent father who had left the family a year earlier when Nin was recovering from a serious surgery. Anaiis' mother, Rosa Nin-Culmell, settled in the outskirts of New York with Anaiis and her two sons and pursued several business ideas to support her family. Though there were more and less affluent times, she was not really a success and the family's life was marked by the modest living conditions that were in relatively sharp contrast with the luxurious context of Nin's European childhood. Nin attended several schools and also took a few courses at Columbia University but never pursued her academic career any further. In June 1922 Nin became engaged to Hugo Guiler, a young American from a good but not overly wealthy family, who was about to embark his career as a banker. Nin and Hugo married in 1923 in Havana.

The early diary of Anaïs Nin covers in much greater detail the adolescence and young womanhood of the author than the diaries of Virginia Woolf and Aino Kallas, offering a wide array of topics concerning the body. The one issue that keeps emerging with considerable stability is the author's strong preference of the matters pertaining to the mind over those pertaining to the body and practices that involve the body such as, for example, housework, sports, and dances. Considering the importance of perceiving herself as an embodied subject that is the focus of Nin's later diaries and the basis of her scandalous and contradictory reputation ${ }^{39}$, such categorical binarization can be considered somewhat unexpected.

Nin developed the practice of keeping the diary that she would fanatically follow all though her lifetime at a relatively young age. Already in adolescence, the intensity of dedication to the diary made it necessary for Nin to cancel and postpone various other activities. According to Nin's biographer Deirdre Bair, Nin tended to neglect her household duties in order to devote herself to the "unbounded egotism of talking about [her] self " $^{40}$. Anaïs Nin herself, however, discusses several times quite ironically how the expectations of her and her brothers differ greatly:

"The dishwasher, the smell of kitchen soap, the dust - choke me! Once I remember wondering if heaven had meant woman for this kind of work. Joaquin ${ }^{41}$ was playing his compositions and I was cooking, having just finished ironing his shirts and mending his socks, in short, attending to his physical comfort. If I had been writing upstairs, he would have not been fed and clothed, and fit to play and compose. Well there, Mimi, stay in the kitchen; genius must be served.»42

38. The diary from the years 1914-1920 is titled Linotte: The Early Diary of Anais Nin. It was published posthumously like all other volumes of Anais Nin's Early Diary.

39. See, Tookey, Helen: «'I am the Other Face of You': Anaïs Nin, Fantasies and Femininity», Women: a Cultural Review, 12-3 (2001), pp. 307-324.

40. Barr, Deidre: Anaïs Nin. A Biography, London, Bloomsbury, 1995, p. 39.

41. Anaïs Nin's younger brother.

42. Nin, Anaïs: Op. cit., p. 270. 
Here Nin's choice of topic very much corresponds to a typical woman's diary. The focus of the collection articles, Inscribing the Daily; Critical Essays on Women's Diaries ${ }^{43}$, for example, is mainly on the characteristic features of the textualization of everyday life in the diary format. Nin's diary, however, quite clearly voices different kinds of expectations of life, and daily events are rarely considered worthy to be mentioned in the diary.

In August 1922, Nin, who is then 19 years old, writes:

«In seeking to know myself and the world and to put my knowledge into words, I have neglected to give my material a human shape, a reality. I have put forth ideas without a body, described emotions and given them no proper setting. /.../ Mine is the story of a soul and of the inner life and of its reactions to the outward life. It is as if ... I was risking to be lost myself in a world of phantoms, spirits and souls. And to lose strength, to lose my grip and hold on the palpable would end in disaster» ${ }^{44}$

In this passage Nin seemingly scolds herself for losing her grip on the palpable world. The passage was triggered by a fear of being unable to communicate with the others while remaining inside her carefully crafted secluded realm of spiritual and intellectual pleasures. The body/mind split, though not Cartesian in origin, commonly carries within it the Cartesian notion of res cogitans and res extensa, "positioning consciousness outside of the world and outside its body [and] removing [it] from direct contact with other minds and a socio-cultural community ${ }^{45}$. It is interesting that Nin's momentary doubt in the status of her position was fuelled by a question that has often been raised in the relation of the Cartesian binary: namely the danger of seclusion, the impossibility of communication in an intellectual framework where consciousness becomes «an island unto itself ${ }^{46}$. Despite this feeling she admits only a few lines later how "like Amiel, sometimes [she] feels each day that [she] is becoming "more purely a spirit; everything is growing transparent to [her]' ${ }^{47}$ and how the surrounding world recedes to mere «matter» waiting to be «spiritualized» ${ }^{48}$.

One of Nin's favorite words in the early diary seems to be 'to soliqualize' and her diary contains numerous descriptions of blissful moments when Nin managed to sneak away from her daily duties and dedicated herself to the activity that mattered most to her. The diary plays, for Nin, a crucial role in her intellectual development; its "mere power of reflecting is worth more to her than all the sermons and advice in the world $»^{49}$. The diary is for her «the strongest help to fulfill her vision to achieve womanhood $\aleph^{50}$. Nin's perception of womanhood, however, does not coincide with that of the people around

43. Amherst, University of Massachusetts Press, 1996.

44. Nin Anaïs: Op. cit., p. 466.

45. Grosz, Elizabeth: Volatile Bodies, Bloomington, Indiana University Press, 1994, p. 7.

46. Ibid., p. 7.

47. Nin Anaïs: Op. cit., p. 466.

48. Ibid., p. 466.

49. Ibid., p. 165.

50. Ibid., p. 165. 
her. One diary entry contains an irritated description of a meeting with a boy named Herbet Ocres who, according to Nin, humiliates her by calling her a "Wonderful girl» ${ }^{51}$. «It cannot be,» writes Nin,

«that I am destined to be judged merely as a pretty doll to play with. Has not all my girlhood been spent in creating my ideal of womanhood and in trying to live up to it - an ideal which is made of all the intangible charms of education, intellect, knowledge?. ${ }^{52}$

Over and over again, the diary positions itself almost categorically against various ways and forms of bodily materiality:

"Woman, primitive and animalized, who rises no higher in her estimation of life than in seeking its physical joys and no higher in her relationship to man than to desire to please his senses - what an obstacle to civilization!... ${ }^{53}$

However, it is not only women who become the object of Nin's criticism. "Hugo", she writes about her husband to be Hugo Guiler, "is essentially a pure physical being above all else»" Hugo dissatisfies Nin for «letting the flesh control his emotions and moods as well as his love» ${ }^{55}$. According to the diary, Nin herself possesses «a control of such degree over her body that the physical is seldom responsible for her acts ${ }^{56}$. In claiming control over her body and simultaneously disclaiming her body, Nin sounds almost heroic in emphasizing her ability to rise above «it all» and act sustained by some inner force which is beyond the human ${ }^{57}$.

Aino Krohn-Kallas, born 1878 into the family of prominent Finnish intellectuals and public figures of Finnish national awakening, is one of the very few women novelists of the first half of the 20th century both in Estonian and Finnish literature still read today. In 1900 she married Oskar Kallas, who was to be a well-known Estonian public figure, with a huge contribution to Estonian culture and education. After marriage they moved to St. Petersburg and a few years later to my hometown Tartu in Estonia. During the years covered in her first diary volume Pärjapunuja. Päevaraamat aastaist 1897-1906 (The Wreathmaker. Diary from the years 1897-1906) ${ }^{58}$, Aino Kallas married, left her homeland, gave birth to four children and published five books.

The early diary of Aino Krohn offers perhaps the most coherent and harmonious description of spiritual as well as corporeal development from

51. Ibid., p. 213.

52. Ibid., p. 213.

53. Ibid., pp. 517-518.

54. Ibid., p. 473.

55. Ibid., p. 473.

56. Ibid., p. 473.

57. Ibid., p. 473.

58. Tallinn, Eesti Raamat, 1994. 
young womanhood to a married woman and a mother of the three diaries considered here. Although she too, like Nin, attributes greater significance to intellectual and creative matters, she retains a generally optimistic view of the effects of her bodily presence throughout her diary. The first part of the volume provides an overview of the typical life of a young woman of her background, highlighting lively social life that has, as one of its primary aims, meeting her future husband. While the attempts of George Duckworth, Virginia Stephen's half-brother, to present Virginia and her sister Vanessa in the upper middle class and aristocratic circles completely failed and while Anaïs Nin is tortured by doubts about her only value as a pretty girl after every dance, Aino Krohn seems to fully enjoy social life. The diary contains various detailed descriptions of parties that the author of the diary considers exciting and fully enjoyable. One of the central social events that the diary touches upon is the ceremony of running for title of the main wreath-maker (in Finnish yleinen seppeleensitojatar) during the graduation ceremony of Finnishspeaking students at Helsinki University in the spring of 1897. Aino Krohn describes her consent in the following way: "The honor was too tempting. I imagined in my mind how they would come to greet me with a song in white student hats and with waving flags. I saw in my mind crowds standing at my window with the eyes of everyone turned to me»" ${ }^{59}$. One the one hand, it is clear that the honor for Aino Krohn does not merely lie in the ceremonial side of the process, as this was an event of some importance for promoting Finnish national identity. On the other, she also confesses to her diary of being flattered by the prospect of being the center of admiring gaze of many male students. The title of the main wreath-maker was finally given to the candidate set up by Swedish-speaking graduates but Aino Krohn participated in the graduation ceremony as the wreath-maker of one of the graduates. Before going to the graduation ceremony, she describes her clothing, "a white dress of slightly yellowish color», "carefully curled black hair» and "a red rosebud attached to her bosom ${ }^{60}$ in rather detailed manner. The description of the dress and hair also demonstrates the author's appreciative evaluation of her body that the carefully chosen attire is meant to accentuate.

While being well aware of and mostly enjoying the attention her looks grant her, she is also conscious of its dangers. During a boat trip to Stockholm with a female relative, Aino Krohn describes how "a finely dressed gentleman» ${ }^{61}$ approaches her during one excursion, wishing to deliver a small note. The diary describes the confusion of the author upon the situation:

"I wanted to read the note, still not realizing what his real aim was, but he stopped me, glancing toward aunt Wenell and repeated his question about my knowledge of German language. When I answered affirmatively, he bent over to me,

59. Kallas, Aino: Pärjapunuja: päevaraamat aastaist 1897-1906, Tallinn, Eesti Raamat, 1994, p. 7. 60. Ibid., p. 10.

61. Ibid., p. 21. 
so close that I could feel his hot breath and said passionately 'Ich intertessiere mich für Ihre Persönlichkeit'. 'I'm interested in your personality'. His gaze, how disgusting it was! I naturally blushed terribly, threw the note by his feet and ran away.» ${ }^{62}$

The extract quoted above reveals quite clearly the hypocritical essence of the situation, the verbally expressed interest of the 'gentleman' in her personality and an interest of quite different kind, communicated via his gaze and hot breath. Aino Krohn, however, is not so much embarrassed but upset that something like this could happen "in broad daylight» ${ }^{63}$. The author is noticeably much more disturbed by the reviews of her first collection of poems that focus more on the author as a pretty young woman than the poetry itself:

"The review was as if written for a child - Roine ${ }^{64}$ diminished my age by two years - or as if for a rather young girl, to whom men feel obliged to pay compliments - about the looks as well. Yes, I was a woman enough to be flattered but someone else in me got offended. /.../ Yes, my looks! I do know that I am pretty and I like it when other people notice it as well but I would never want this to be the only noteworthy thing about me.» ${ }^{65}$

In some sense this is a classic case of masculinist criticism of a work of literature by a woman author that has been pointed out by many feminist literary critics: the attention focuses only on the author's looks and the work itself becomes secondary ${ }^{66}$. Aino Krohn bitterly criticizes the author of the review for foregrounding the "pretty young girl of letters ${ }^{67}$ in a patronizing and objectifying manner over the text itself and refuses to accept his discouraging view of her future career as a writer since she is a young woman whose primary objective in life should be finding a proper husband.

Issues pertaining to the relationship between her mind and her body become central during Aino's engagement to Oskar Kallas. The diary entries offer an extremely interesting insight into a young woman's mind concerning the different sides of an ideal relationship between a husband and a wife. Aino Krohn admits that she has had to fight with "the pressure of the leading way of thought that builds a wall around a young girl» ${ }^{68}$. The central issue here is normative behavior concerning the physical side of marriage.

"A young girl is brought up so that she almost never - or very seldom - marries self-consciously, she should not wish to yield to a man, she should not feel it in herself as a force of nature or a demand. She is taught that this is an inevitability

62. Ibid., p. 21.

63. Ibid., p. 21.

64. The author of the review.

65. Kallas, Aino: Op. cit., p. 26.

66. See, for example, ATwood, Margaret: «Paradoxes and Dilemmas: The Woman as Writer», in Gwen Matheson (ed.), Women in the Canadian Mosaic, Toronto, Peter Martin Associates, 1976, p. 273.

67. Kallas, Aino: Op. cit., p. 26.

68. Ibid., p. 169. 
that she has to surrender to, no matter how difficult it would be for her, because the husband desires her. That this could also mean something to her, she should not know.»" ${ }^{69}$

This reveals a very interesting paradox concerning the nature of marriage. As the beginning of the early diary clearly demonstrates, the whole life of a young woman presented in society circles around marriage. At the same time, however, the woman is nothing more than a passive object who, upon her marriage, does not express her own will or wishes but merely follows the norms prescribed by the society. Those norms also require that in the intimate relationship with her husband, the woman should passively surrender.

Aino Krohn has also grown up hearing the matters concerning physical relationship between a man and a woman being "discussed in secret, in covert manner as if they were shameful in essence ${ }^{70}$. During her engagement, Aino Krohn contemplates on these matters very thoroughly, admitting to her diary though, that she has been unable to formulate all of it into words ${ }^{71}$. The conclusion she finally reaches differs considerably from the norm:

"First I shared this point of view but to my surprise I started feeling differently. I felt a desire to give myself completely, so completely that I could as if melt into the being of the other, to get so close that I would not feel the borderline between myself and him. ${ }^{72}$

Such argumentation shows the authors considerable boldness in resisting the norms of morality of her time and going beyond them by openly claiming her desiring quite natural and granting it, albeit not without some hesitation, an honorable position beside her mind and soul outside the denigrating binary oppositions. Secondly, the way Aino Krohn explores the desires of her newly discovered body is very interesting in its potential readiness to dissolve it's border, a body that its characterized by its volatile rather than its' solid and rigid capacities.

The development of embodied subjectivity in the early diaries of Virginia Woolf, Anaïs Nin and Aino Kallas varies in mode of expression and scope. The differences can be attributed to the variations in the normative setup of the cultural contexts of the authors as well as differences in their diaristic style. Virginia Woolf's diary contains very few entries that focus on the author's self-perception. While the aspects concerning the body and embodiment form no exceptions to the general structure of the diary, despite the fragmented and implied manner, however, they still emerge as a matter of some importance. The most visible aspect related to the body emphasized in Woolf's early diary

69. Ibid., p. 169.

70. Ibid., p. 169.

71. Ibid., p. 169.

72. Ibid., p. 169. 
is the wish to retain from contact with unfamiliar bodies and the need for sharing the same physical space with people close to her. Anaïs Nin's diary strongly foregrounds the binary opposition of mind and body. The body and its manifestations are for Nin clearly obstacles for intellectual and spiritual development that have to be overcome in every possible way. Focusing first and foremost on the conflict between the two sides of the binary, the processes of suppressing and disclaiming the bodily emerge alongside the author's quest for intellectuality and spirituality. The early diary of Aino Kallas contains perhaps the most harmonious view of embodied subjectivity. Being well aware of the social norms creating the body/mind binary, Aino Kallas strives against them in order to find a perception of the body that would make it a fully recognizable and legitimized part of her subjectivity. Such embodied subjectivity finds its fullest expression in the entries from the period of the author's engagement to Oskar Kallas, viewing body and mind as interconnected and inseparable parts of subjectivity. 